MINERALOGIA, 48, No 1-4: 39-45 (2017)

DE DE GRUYTER OPEN

DOI: $10.1515 / \mathrm{mipo}-2017-0010$

www.Mineralogia.pl

MINERALOGICAL SOCIETY OF POLAND

Polskie TOWARZYSTWO MINERALOGICZNE

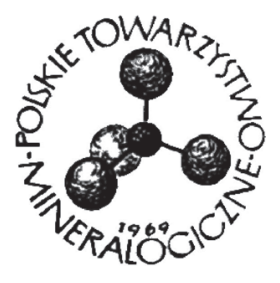

Original paper

\title{
Current stage of knowledge relating to the use ferruginous sludge from water treatment plants - a preliminary review of the literature
}

\author{
Magdalena Wołowiec ${ }^{1}$, Tomasz Bajda ${ }^{1 *}$ \\ ${ }^{I}$ AGH University of Science and Technology, Faculty of Geology, Geophysics and Environmental Protection, al. \\ A. Mickiewicza 30, 30-059 Kraków, Poland \\ * Corresponding author \\ e-mail: bajda@agh.edu.pl
}

Received: May 13, 2017

Received in revised form: August 8, 2017

Accepted: August 26, 2017

Available online: September 30, 2017

\begin{abstract}
In water treatment plants, a large amount of wastewater and sludge is generated during the processing of drinking water. The composition of the sludge is determined by the type and raw water chemistry, as well as the methods and materials used for purification. The major components of the sludge are iron and manganese oxyhydroxides. In the past, the sludge was landfilled, but for environmental reasons it became necessary to find uses for the sludge. The aim of this study was to identify examples of using this sludge. Nowadays, the sludge is applied in the treatment of municipal wastewater, agriculture, and the production of cement and bricks, among others. Attention was also paid to the possibility of using the water processing sludge in different sorption applications.
\end{abstract}

Key-words: water treatment residuals, reuse, water treatment, plant sludge management

\section{Introduction}

While processing drinking water, especially surface water, much wastewater and sludge is created (Kyncl et al. 2012). The quality of water intended for human consumption is regulated by the Minister of Health through the regulation of November 13, 2015 (the Regulation of the Polish Minister of Health of March 29, 2007, as amended on November 13, 2015). Environmental protection imposes limits on waste generation. However, it is not 
possible to place restrictions that lead to reductions in the amount of purified drinking water produced. Therefore, what is needed is to find ways for the harmless disposal and reuse of this sludge as a secondary raw material.

The quantity of backwash water varies from $2 \%$ to $5 \%$ of the whole volume of processed water. This is an imperative issue that should be addressed in drinking water management (Kyncl et al. 2012). In the case of using the sludge as sorbents, they first have to be dewatered and dried before they can be applied (Balcerzak, Luszczek 2015). The choice of water purification methods depends on many factors, such as the origin and physicochemical composition of the processing water (Nowacka, Włodarczyk-Makuła 2014).

As recently as in the nineties, the sludge produced in water treatment plants was often drained directly into rivers, or into empty reservoirs such as sand pits or man-made reservoirs (Varlicchi, Masotti 2000). Due to increasingly tightened law and regulations relating to the quality and protection of surface water, many waste management methods have been developed. Figure 1 presents the current techniques for the utilization of the sludge from water treatment plants in Poland (Jaroszyński et al. 2011).
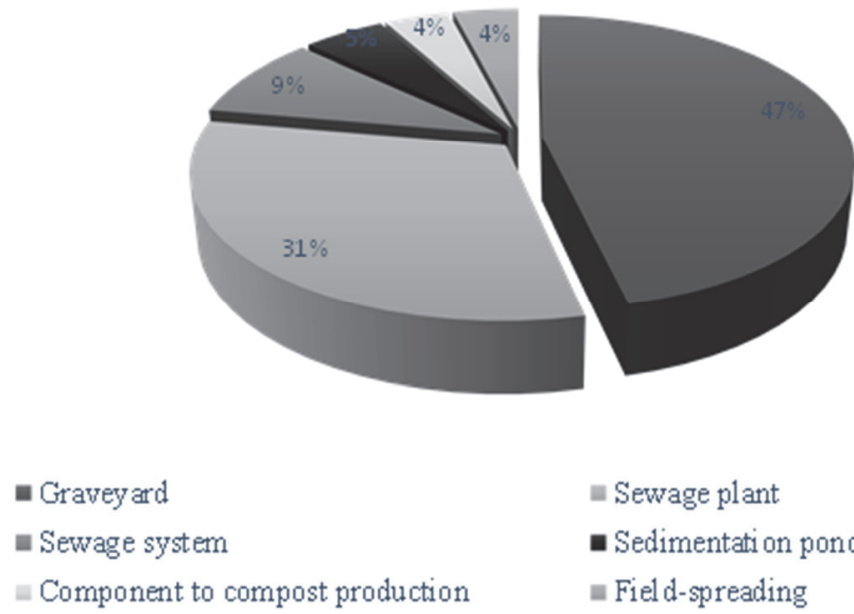

$$
\begin{aligned}
& \text { - Sewage plant } \\
& \text { - Sedimentation pond (lago on) } \\
& \text { = Field-spreading }
\end{aligned}
$$

Fig. 1. Current approaches for the utilization of sludge from water treatment plants.

The recent literature has suggested that several hundred tons of solid residuals are produced each year in Europe (Babatunde, Zhao 2007), and that global sludge production might total 10000 tons/day (Dharmappa et al. 1997; Gibbons, Gagnon 2010). It is predicted that this amount will increase due to the requirements for purified water (Dymaczewski et al. 2009). According to GUS (Central Statistical Office of Poland) data, the amount of sludge produced from water treatment in Poland in 2014 was 2.4 million tons, of which only 0.5 million tons was recovered (Statistical Yearbook of the Republic of Poland 2014).

The aim of this paper was to prove that the landfilling of water treatment residuals rich in iron is not the only way to manage them. Different methods of using sludge are 
presented here, such as for a component of brick and cement production, application in municipal sewage systems or in agriculture. Recently, attention has been paid to using ferruginous sludge as sorbents of different anions and cations.

\section{Experimental}

\subsection{Materials}

The composition and properties of sludge produced in water treatment plants are diversified and depend on various factors, such as the type and composition of the processed water, and the methods and materials used for treatment (Hirol et al. 2009). The composition of surface water is variable, which causes the production of sludge with large quantitative and qualitative differences. Common pollutants removed from surface water are clay minerals, clay and sand particles, and organic substances. Processing underground water causes the formation of sludge, where the quality and quantity are almost consistent. The sludge mainly contains iron and manganese oxyhydroxides, which are precipitated from the water.

In Poland, the simplest iron and manganese removal processes are most commonly used. They consist of aeration and air filtration processes, alternatively supplemented by a sedimentation process if the concentration of iron and manganese exceeds $10 \mathrm{mg} / \mathrm{L}$. This classic groundwater treatment technology allows the removal of trace amounts of iron and manganese.

The iron and manganese removal process involves the oxidation of $\mathrm{Fe}(\mathrm{II})$ to $\mathrm{Fe}(\mathrm{III})$ and the removal of $\mathrm{Fe}(\mathrm{OH})_{3}$ (Krajewski 2001). The process of removing iron in a simplified form is presented below:

$$
\begin{gathered}
\mathrm{Fe}\left(\mathrm{HCO}_{3}\right)_{2}+2 \mathrm{H}_{2} \mathrm{O} \rightarrow \mathrm{Fe}(\mathrm{OH})_{2}+2 \mathrm{CO}_{2}+2 \mathrm{H}_{2} \mathrm{O}, \\
\mathrm{Fe}^{2+}+0.25 \mathrm{O}_{2}+2.5 \mathrm{H}_{2} \mathrm{O} \rightarrow \mathrm{Fe}(\mathrm{OH})_{3}+2 \mathrm{H}^{+}
\end{gathered}
$$

Iron salts present in water easily hydrolyze to soluble iron (II) hydroxides, and then they oxidize and precipitate as sparingly soluble iron (III) hydroxide, which is the main component of the sludge. The amount of $\mathrm{Fe}(\mathrm{OH})_{3}$ depends on the iron concentration, the amount of processed water, the degree of oxidation from $\mathrm{Fe}(\mathrm{II})$ to $\mathrm{Fe}(\mathrm{III})$, and the sedimentation and filtration efficiency. From the underground water, manganese compounds are removed too. However, their concentration is much lower, and therefore the sludge is called ferruginous (Szerzyna 2012).

According to Wołowiec et al. (2017), the chemical and mineralogical composition of the sludge were diversified. $\mathrm{Fe}_{2} \mathrm{O}_{3}$ content varied from 18 to $53 \mathrm{wt} . \%$, whereas they contained from 5 to $62 \mathrm{wt} . \% \mathrm{SiO}_{2}$. The samples rich in iron were composed predominantly of ferrihydrite, while quartz and calcite were identified as admixtures. The samples rich in silica were composed of quartz and feldspar, with minor admixture of calcite. The water treatment residuals contained large amounts of arsenic $(29-1652 \mathrm{ppm})$, barium (1175 $3256 \mathrm{ppm})$, zinc $(243-836 \mathrm{ppm})$ or strontium $(220-464 \mathrm{ppm})$. The specific surface area of the sludge was $35-170 \mathrm{~m}^{2} / \mathrm{g}$. The share of each of the classes of pores throughout the whole pore volume was as follows: share of micropores: $16-32 \%$; share of mesopores: 46 - 55\%; share of macropores: $21-30 \%$ (Wołowiec et al. 2017). 


\subsection{Analytical methods}

The chemical composition was obtained by wavelength dispersive X-ray fluorescence spectroscopy (WD-XRD) and inductively coupled plasma atomic emission spectroscopy (ICP-AES). The sludge was characterized by X-ray diffraction (XRD) with an X-ray powder diffractometer (Philips APD PW 3020 X'Pert diffractometer with graphite monochromator) using $\mathrm{CuK} \alpha$ radiation, a step size of $0.05^{\circ} 2 \Theta$ and scanning rate of $1 \mathrm{sec}$ per step. Air dried uncoated samples were analyzed by electron microscopy using a variable pressure field emission scanning electron microscope ([FE-SEM], FEI Quanta 200) equipped with an energy dispersive spectrometer (EDS) for elemental microanalysis. The $\mathrm{S}_{\mathrm{BET}}$ and porosity were determined from $\mathrm{N}_{2}$ gas adsorption/desorption isotherms at $77 \mathrm{~K}$ after outgassing for $12 \mathrm{~h}$ at $373 \mathrm{~K}$ using an ASAP 2020 apparatus (Micromeritics). The BET equation was used for the $\mathrm{S}_{\mathrm{BET}}$ calculations (Brunauer et al. 1938). The $V_{t o t}^{0.99}$ was calculated from the amount of $\mathrm{N}_{2}$ adsorbed at a relative vapor pressure $\left(\mathrm{P} / \mathrm{P}_{0}\right) \sim 0.99$.

\section{Results}

\subsection{Using the ferruginous sludge for hydrogen sulfide binds}

Hydrogen sulfide is a toxic gas that causes the corrosion of concrete and metal sewage equipment and generates unpleasant odors. This compound is also dangerous for human health and life, especially for maintenance workers. A paper by Jaroszyński et al. (2011) reported that water treatment residuals can be used for $\mathrm{H}_{2} \mathrm{~S}$ binding in anaerobic manure fermentation and for $\mathrm{H}_{2} \mathrm{~S}$ binding during tanning treatment. Tanning waste from the cleaning of hides contains large amounts of chlorides and sulfides. These are cleaned in overhead compensatory tanks. However, the amount of supplied air does not always allow for their full oxidation, and so the concentrated sludge from groundwater treatment stations is used because this allows for the complete application of these compounds. Furthermore, the use of the sludge is much cheaper than the use of iron sulfate, which is mainly applied in such processes (Oostelbos 1988; Jaroszyński et al. 2011).

\subsection{Drainage of sludge to the municipal sewage system}

Draining the sludge to the municipal sewage system depends on the proximity to the sewage network. In this case, many conditions must be achieved; for example, the sludge should be evenly distributed. In the sewage system, the minimum speed of the mixture of sewage and sludge must be maintained. This method leads to enhancing the effects of mechanical wastewater treatment by increasing the volume of sludge generated in the sewage treatment plant, reducing gas production in methane fermentation, and removing phosphorus (Jaroszyński et al. 2011). After adding water processing sludge containing 50 $\mathrm{mg} / \mathrm{L}$ of iron, the phosphorous content was reduced to below $2 \mathrm{mg} / \mathrm{L}$ (Kyncl et al. 2012). Totczyk et al. (2015) also proved that ferruginous sludge can remove phosphates. Phosphates are adsorbed by iron salts during precipitation. During experiments, the 
concentration of phosphates in sewage decreased from 11 to $0.8 \mathrm{mg} \mathrm{PO}_{4} / \mathrm{L}$, and the removal efficiency was $92.73 \%$ (Totczyk et al. 2015).

\subsection{Ferruginous sludge as a component of cement}

According to Kreft (1988), ferruginous sludge can be used in cement production; however, heavy metal concentrations cannot exceed standards (e.g. the concentrations of undesirable heavy metals cannot be higher than in the natural resources used in cement production) and the sludge must be dewatered. The water treatment residuals must also be homogenous and contain as little insoluble organic substances as possible. Using the sludge instead of traditional materials during cement production reduced the cost of production of a single concrete block by up to $40 \%$ (Kaosol 2009). Using sludge as a component of cement is one of the cheapest and most effective methods of sludge management.

\subsection{Using ferruginous sludge in agriculture}

Applying sludge in agriculture or forests is a good idea; however, some restrictions must be applied. The process cannot be dangerous and should not have any negative influence on the environment; therefore, defining the content of heavy metals, organic compounds and nutrients is required (Różanowski et al. 2012). Study related to the use of the sludge from the Podhradi Water Treatment Plant conducted by Knycl et al. (2007) proved that applying the sludge to light soil was an effective solution. The analyzed samples contained relatively high content of organic compounds in the dry matter. There were no negative effects, the plants remained in good condition and even the concentration of humus in the soil increased (Kyncl et al. 2012).

\subsection{Ferruginous sludge as a clay replacement and colorant in facing bricks}

In a study conducted by Dunster et al. (2007), it was found that ferruginous sludge can be used during brick production, as a substitute for clay or some colorants. The brick market is interested in materials which can guarantee specific colors. Bricks which are produced from high iron content water treatment residuals are characterized by an intense red color. Another asset is utilizing a material from a sustainable source. The use of alternative substrates is considered mainly when clay or colorants are not found locally and where the cost in combination with the properties of the water treatment residuals is advantageous (Dunster et al. 2007).

\subsection{Using ferruginous sludge in sorption experiments}

Recently, increasing attention is being paid to using ferruginous sludge as a sorbent for different heavy metals, metalloids and so on, as the sludge has surprisingly good sorption capacity.

The sorption properties of ferruginous sludge in terms of the aqueous solution of $\mathrm{Cd}(\mathrm{II})$, $\mathrm{Pb}(\mathrm{II}), \mathrm{Zn}(\mathrm{II}), \mathrm{Cu}(\mathrm{II}), \mathrm{Cr}(\mathrm{III}), \mathrm{Cr}(\mathrm{VI})$ and $\mathrm{As}(\mathrm{V})$ were evaluated by Wołowiec et al. (2017). The water treatment residuals revealed very good sorption properties. Cation sorption 
efficiency was almost $100 \%$, even at the highest metal concentrations. In the case of anions, it ranged between $50 \%$ and $100 \%$. The sorption properties appeared to depend on the mineral and chemical composition of the sludge. The more iron compounds and loss of ignition (LOI) in the sample, the higher the sorption capacity. Furthermore, the higher the specific surface area, the greater the amount of removed pollutants (Wołowiec et al. 2017).

\section{Conclusions}

The processing of drinking water sludge and wastewater cannot be avoided. In Poland, water treatment residuals are still mainly landfilled, which may cause a range of environmental problems. Nevertheless, there are many different methods of using the sludge. One of the best methods is using ferruginous sludge as a component in cement production, which is cheap and preferable to drainage into the municipal sewage system. Water treatment sludge can also be used for $\mathrm{H}_{2} \mathrm{~S}$ binding in anaerobic manure fermentation and for $\mathrm{H}_{2} \mathrm{~S}$ binding during tanning treatment. Ferruginous sludge is also a great sorbent of different anions, and is even more efficient than popular adsorbents such as clay minerals, fly ash or zeolites.

Acknowledgements. This work was supported by AGH-UST Statutory Grant No. 11.11.140.319.

\section{References}

Babatunde, A.O.; \& Zhao, Y. Q. (2007). Constructive approaches toward water treatment works sludge management: an international review of beneficial reuses. Critical Reviews in Environmental Science and Technology 37, 129-164. DOI: 10.1080/10643380600776239

Balcerzak, W., \& Łuszczek, B. (2015). Próba oceny możliwości wykorzystania osadów z procesów klarowania wody do strącenia związków fosforu w oczyszczalniach ścieków komunalnych. Ochrona Środowiska, 37, 5760. [in Polish]

Brunauer, S., Emmett, P. H., \& Teller, E. (1938). Adsorption of gases in multimolecular layers. Journal of American Chemical Society, 60, 309-319. DOI: 10.1021/ja01269a023.

Dharmappa, H. B. Hasia, A., \& Hagare, P. (1997). Water treatment plant residuals management. Water Science and Technology, 35, 45-56. DOI: 10.1016/S0273-1223(97)00150-9.

Dunster, A., Petavratzi, E., \& Wilson, S. (2007). Water treatment residues as a clay replacement and colorant in facing bricks. Case Study: WTR 177/WR0115, Microbe.

Dymaczewski, Z., Jeż-Walkowiak, J., Komorowska-Kaufman, M., Krajewski, P., \& Sozański, M. M. (2009). Water treatment plant residuals management. Proceedings: Current issues in water treatment and water distribution, 10-12 June 2015 (29-36). Szczyrk, Politechnika Śląska, Instytut Wody i Ścieków.

Gibbons, M. K., \& Gagnon, G. A. (2010). Understanding removal of phosphate or arsenate onto water treatment residuals solids. Journal of Hazardous Materials, 186, 1916-1923. DOI: 10.1016/j.hazmat.2010.12.085.

Hirol, A. M., Boychuk, S. D., Girol, A. M., Hirol, M. M., Kowalski, D., \& Łagód G. (2009), Flushing water and sediments utilization from selected water treatment station, Proceedings of ECOpole, 3, 311-316.

Jaroszyński, T., Krajewski, P., \& Grześkowiak, K. (2011). Praktyczne wykorzystanie osadów żelazowych z procesów uzdatniania wody. Technologia Wody, 2(10), 26-33.[in Polish]

Kaosol, T. (2009). Reuse water treatment sludge for hollow concerete block manufacture, International Conference on Science, Technology and Innovation for Sustainable Wellbeing (STISWB), Mahasarakham University, Thailand, 23-24 July, 1-5.

Krajewski, P. (2001). Metody unieszkodliwiania osadów i popłuczyn. Przegląd Komunalny, 11, 106-111. [in Polish] 
Kreft, W. (1988). Entsorgung im Zementwerk. Verwertung von Rest - und Abffallstoffen, durch die Zementindustrie, Entsorgungs Praxis, 9, 360. [in German]

Kyncl, M., Cihalova, S., Jurokowa, M., \& Langarova, S. (2012). Disposal and Reuse of Water Processing Sludge. Journal of the Polish Mineral Engineering Society, 13, 2, 11-20.

Nowacka, A., \& Włodarczyk-Makuła, M. (2014). Charakterystyka osadów powstających w procesach uzdatniania wody ze szczególnym uwzględnieniem osadów pokoagulacyjnych. Technologia Wody, 6(38), 34-39. [in Polish]

Oostelbos, P.G. (1988). An approach to the sludge problem at the Noordbergum, Oldenholtpade, Spannenburg, and Terwisscha water treatment plants, Water Company, Friesland, The Netheralnds.

Różanowski, B., Michałowski, M., Tora, B., Cablik, V., \& Cernotova L. (2012). Effectiveness of the use of willow tree (Salix Viminalis) for wastewater treatment. AGH Journal of Mining and Geoengineering, 36, 4, 159-165.

Szerzyna, S. (2012). Porcjowe grawitacyjne zagęszczanie osadów powstająctch w różnych układach oczyszczania wody. Doctoral dissertation. Instytut Inżynierii i Ochrony Środowiska. Politechnika Wrocławska, Wrocław, Polska. [in Polish]

Totczyk, G., Klugiewicz, I., Pasela, R., \& Górski, Ł. (2015). Usuwanie fosforanów z wykorzystaniem osadów potechnologicznych pochodzących ze stacji uzdatniania wody. Annual Set The Environmental Protection, 17, 1660-1673. [in Polish]

Verlicchi, P., \& Masotti, L. (2000). Reuse of drinking water treatment plants sludges in agriculture: Problems, perspectives and limitations. Technology transfer. Proceedings of the $9^{\text {th }}$ International Conference on the FAO ESCORENA Network on recycling of agricultural, municipal and industrial residues in agriculture September 6-9, 67-73. Gargano, Italy.

Wołowiec, M., Bajda, T., Rzepa, G., Drewniak, Ł., Debiec, K., Komorowska-Kaufman, M., \& Pruss, A. (2017). Sorption properties of ferruginous sludge from Water Treatment Plant. Proceedings: $18^{\text {th }}$ International Conference of Young Geologists 2017, 30 March - 2 April 2017, Dobczyce, Poland.

Statistical yearbook of the Republic of Poland, (2014).

The Regulation of the Minister of Health of March 29, 2007, as amended on November 13, 2015 changing Regulation on the quality of drinking water for man, Warsaw, Poland Government Publishing Service. 